\title{
Effect of Prosopis farcta extracts on some complications (hematology and lipid profiles) associated with alloxan induced diabetic rats
}

\author{
I.H. Mohammed ${ }^{1}$ and E.S. Kakey ${ }^{2}$ \\ ${ }^{1}$ Department of Medical Microbiology, ${ }^{2}$ Department of Biology, Faculty of Science and Health, Koya University, Koya \\ KOY45, Kurdistan Region - F.R. Iraq, Email: ${ }^{1}$ ismael.hasan@koyauniversity.org, ${ }^{2}$ esmail.kakey@koyauniversity.org
}

(Received March 16, 2019; Accepted May 12, 2019)

\begin{abstract}
This study aimed to investigate the effects of ethyl acetate Prosopis farcta extracts on some complications associated with diabetes in rats. The experimental rats of 1.5-2 months old that weighed 190-220 g were randomly divided into six groups of seven animals each. Body weight, serum glucose, hematological changes and lipid profiles were studied. Alloxan was used of induction diabetes in rats. 252 rats were used and different doses of the ethyl acetate extracts of roots, fruits, and leaves of $P$. farcta were orally administered daily for 28 days for normal and diabetic rats and the effective dose was $200 \mathrm{mg} / \mathrm{kg}$ BW for each kind of extracts. The results showed that administration of root, leaves and fruit extracts of $P$. farcta caused improvement in body weight, blood glucose, red blood cells (RBCs), hemoglobin ( $\mathrm{Hb})$, mean corpuscular hemoglobin $(\mathrm{MCH})$, hematocrit (HCT or PCV) in alloxan diabetic rats in insulin like treatment manner, with the most effective improving effect for roots extract. Regarding to the effects on total and differential white blood cell (WBC) count, administration of extracts caused decrease in the total WBC and neutrophil count. Administration of root, leaves and fruit extracts of $P$. farcta, showed suppression in total cholesterol (TC), triglyceride (TG), very low-density lipoprotein (VLDL-C) and low-density lipoprotein (LDL-C), and increasing in high density lipoprotein (HDL-C) of alloxan diabetic rats. In conclusion, the P. farcta extracts possesses properties of improving some health complications accompanied diabetes in rats.
\end{abstract}

Keywords: Prosopis farcta, Lipid, Diabetic rats

Available online at http://www.vetmedmosul.com, (C) 2020, College of Veterinary Medicine, University of Mosul.

This is an open access article under the CC BY 4.0 license (http://creativecommons.org/licenses/by/4.0/).

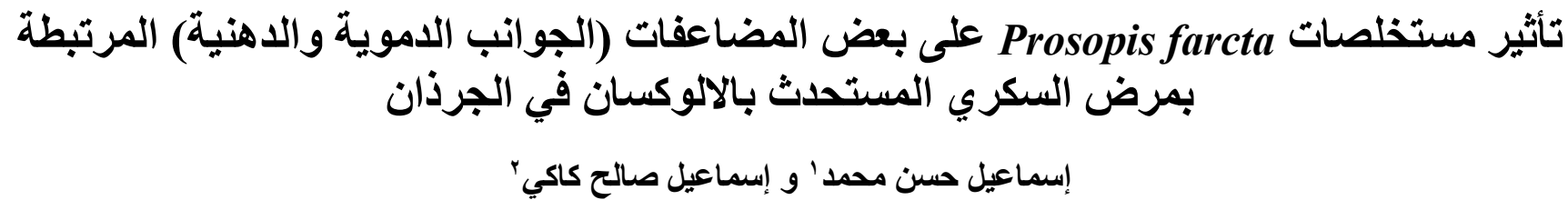

$$
\text { ' فرع الأحياء المجهرية الطبية، ` فرع علم الأحياء، كلية العلوم و الصحة، جامعة كويه، أربيل، العراق }
$$

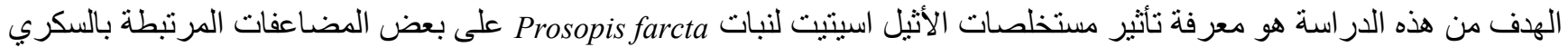

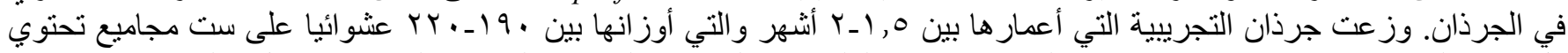

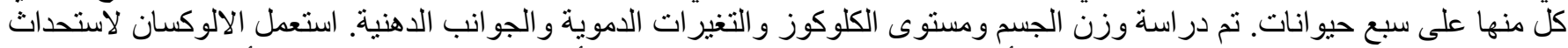

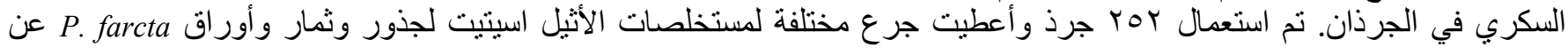

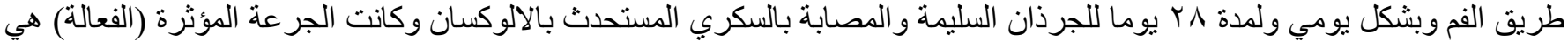

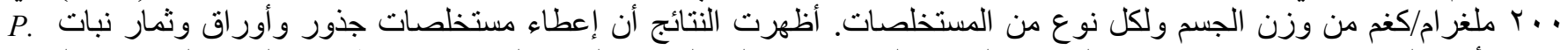

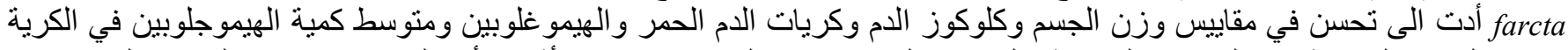

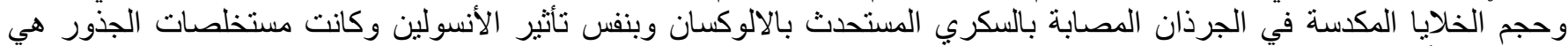

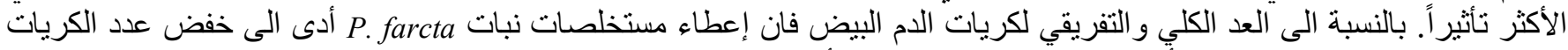
الدم البيض الكلي و عدد العدلات. أُظهرت مستخلصات جذور وأور اق وثمار نبات P. farcta انخفاضا في مستويات الكوليسترول الكلي 


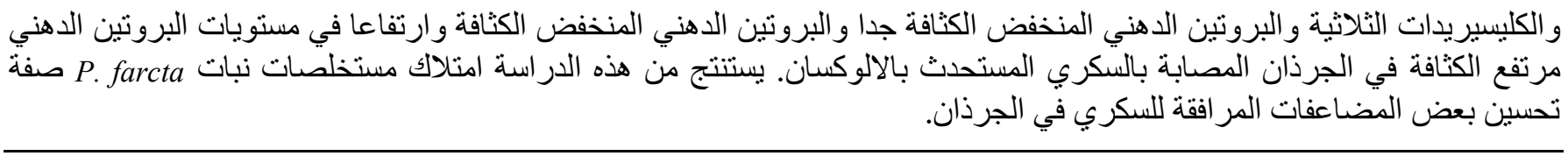

\section{Introduction}

Prosopis farcta extract was mentioned in the treatment of diabetes in traditional medicine (1). The hypoglycemic activity of an aqueous solution of the lyophilized root extract of Prosopis fracta was proven in normoglycemic and streptozocin-induced hyperglycemic rats when given orally (2). High blood sugar in diabetes mellitus has different effects on red blood cells count. Previously demonstrated a significant positive correlation between $\mathrm{Hb}$, HCT, and mean corpuscular hemoglobin concentration (MCHC) with Hemoglobin A1c (HbAlc) values (3). Total white blood cell (WBC) count is another inflammatory marker, which is related to many health problems such as impaired glucose tolerance and type 2 diabetes (4). Dyslipidemia is common in diabetes and usually decreasing cholesterol concentrations improve cardiovascular outcomes. Improved glycemic control generally has positive effects on lipoprotein levels in diabetes. Cardiovascular are directly related to lipoprotein metabolism and indirectly to the glycemic state (5). Natural products have good roles in the prevention of obesity and associated metabolic diseases (6). Previous research confirmed the efficacy of $P$. farcta beans powder as a beneficial agent to decrease LDL-C cholesterol and increase HDL-C cholesterol concentration, indicating a hypolipidemic property of $P$. farcta (7).

Due to a little of ongoing studies in the hematological measures and lipid profiles in P. farcta in type 1 diabetes, we conducted this study to explain the effect of $P$. farcta on blood constituents as well as lipid profiles in this type of diabetes by rats as a model.

\section{Materials and methods}

\section{Plant material}

The roots, leaves, and fruits of $P$. farcta were collected from Koya city in Erbil Governorate, Iraq, in July 2017. The plants were identified in the Herbarium of Medicinal Plants and Drugs Research Institute, Shahid Beheshti University, under the herbarium codes of MPH-1296 and MPH-1342, respectively.

Ethyl acetate was chosen for extraction of roots, leaves and fruits of $P$. farcta. The plant materials were dried at room temperature and grinded by the mechanical grinder. $10 \mathrm{~g}$ of each plant powder was extracted with ethyl acetate $(3 \times 50 \mathrm{ml})$ by maceration on a magnetic stirrer for $1 \mathrm{~h}$ at room temperature. The extracts were evaporated to dryness under reduced pressure at $45^{\circ} \mathrm{C}$.
252 Albino rats male rats aged 1.5-2 months and weighed 190-220 gm. have been used. Diabetic case induced by a single subcutaneous injection of $120 \mathrm{mg}$ alloxan $/ \mathrm{kg}$ b.w (8). The ethyl acetate extracts of $P$. farcta (roots, leaves, fruits) were orally administered daily for 28 days with different doses $(50,100,150,200,250,300 \mathrm{mg} / \mathrm{kg})$ in $1 \mathrm{ml}$ of physiological saline for each kind of extract. Group I, non-treated rats administered $1 \mathrm{ml}$ physiological saline; Group II alloxan-induced diabetic rats, administered $1 \mathrm{ml}$ physiological saline; Group III alloxan-induced diabetic rats, administered roots extract; Group IV alloxaninduced diabetic rats administered leaves extract; Group V alloxan-induced diabetic rats administered fruits extract; and Group VI alloxan-induced diabetic rats subcutaneously administered insulin (Actrapid .Novo Nordisk, Denmark) (10 I.U/Kg of body weight) (9). Each analysis was calculated from the difference between the initial at the beginning and the final at the end of the experiment (after 28 days).

The inhibitory effect of each kind of the extracts was evaluated after a 28 days period using area under the blood glucose inhibition curve. Curves of blood glucose concentration $(\mathrm{mg} / 100 \mathrm{ml})$ vs. extract concentrations $\mathrm{mg} / \mathrm{kg}$ were constructed. Concentrations (doses) 200, 250 and 300 $\mathrm{mg} / \mathrm{kg}$ b.w. showed the best similar inhibition for glucose levels, and the $200 \mathrm{mg} / \mathrm{kg}$ b.w was the lowest concentration among them, therefore it selected as an effective dose. As the same way the effective dose was selected for parameters of body weight, hematology and lipid profiles and it was $200 \mathrm{mg} / \mathrm{kg}$ b.w for all extracts (roots, leaves, fruits) and all parameters (10).

\section{Parameters measurement}

The body weight (grams) of each rat was assessed using a balance before and after 28 days. Blood samples were taken from orbital sinus of each animal. Hematology parameters $\mathrm{RBC}, \mathrm{Hb}, \mathrm{HCT}$, mean corpuscular volume (MCV), MCH, MCHC, WBC, Neutrophils, Lymphocytes, Monocytes were estimated using fully automated Coulter counter system. The biochemical parameters which included serum glucose and serum lipid profiles TC, TG, VLDL, LDL, and HDL were determined on the sera specimen by using the Cobas diagnostic kit with fully automated chemical analyzer (Cobas C 311). The VLDL was calculated from the following equation: $\mathrm{VLDL}=\mathrm{TG}$ $(\mathrm{mg} / \mathrm{dL}) / 5(11)$. 


\section{Statistical analysis}

Data of the current study was expressed as mean, standard error of the mean (Mean \pm SEM) and SPSS (statistical package for social science) (Version 24) statistical software was used to analyze the data. Post hoc multiple comparison tests for one-way analysis of variance (ANOVA) was used to investigate the relationship of the parameters. Level of probability $(\mathrm{P}<0.05)$ to find significance was considered (12).

\section{Results}

The effective dose was $200 \mathrm{mg} / \mathrm{kg}$ for each kind of extract (roots, leaves and fruits) therefore, we considered it in our results, but other doses did not show significant changes.

Effect of $P$. farcta extracts (roots, leaves and fruits) on the serum glucose in alloxan induced diabetic rats

Table 1 elucidates the effects of Prosopis farcta extracts on serum glucose level in normal and diabetic male rats. Incidence of diabetes caused hyperglycemia in the rats. Among the extracts effects, the root extract was more reduced to the glucose. The highest reduction was in the third week of administration of the root extract as compared with other two extracts in diabetic rats, but their hyperglycemic effect was less than effect of insulin. The second one was leave extract then the extract of fruits.

Table 1: Effect of $P$. farcta extracts (roots, leaves and fruits) on serum glucose level in alloxan-induced diabetic rats

\begin{tabular}{lcccc}
\hline \multirow{2}{*}{ Animal groups } & \multirow{2}{*}{ Before treatment } & \multicolumn{3}{c}{ After treatment } \\
\cline { 2 - 4 } & $92.00 \pm 4.461$ & $1^{\text {st }}$ week & $2^{\text {nd }}$ week & $3^{\text {rd }}$ week \\
\hline Normal control rats & $465.0 \pm 24.97$ & $495.0 \pm 24.60$ & $93.00 \pm 5.831$ & $93.00 \pm 6.819 \mathrm{a}$ \\
Diabetic rats & $448.0 \pm 30.36$ & $284.0 \pm 15.03$ & $451.0 \pm 20.76$ & $446.0 \pm 17.20 * \mathrm{~b}$ \\
Diabetic rats+ root extract & $448.0 \pm 28.04$ & $304.0 \pm 10.30$ & $286.0 \pm 10.77$ & $176.2 \pm 8.375 * \mathrm{c}$ \\
Diabetic rats+ leaves extract & $465.0 \pm 25.00$ & $306.0 \pm 12.08$ & $291.0 \pm 6.071$ & $274.0 \pm 9.274 * \mathrm{~d}$ \\
Diabetic rats+ fruits extract & $467.0 \pm 22.51$ & $153.0 \pm 13.38$ & $132.0 \pm 11.47$ & $300.0 \pm 10.49 * \mathrm{e}$ \\
Diabetic rats+ insulin & & &
\end{tabular}

Results expressed as mean \pm St. error. * means significant difference with serum glucose levels before treatment at $\mathrm{P}<0.05$ in the same rows. The same letters in the same column mean non-significant difference, while the different letters mean significant difference at $\mathrm{P}<0.05$.

Effect of $P$. farcta extracts (roots, leaves and fruits) on the body weight in alloxan induced diabetic rats

Table 2 shows the effect of $P$. farcta extracts of roots, leaves and fruits at $200 \mathrm{mg} / \mathrm{kg}$ on body weight of normal and diabetic male rats. The incidence of diabetes by an alloxan reduced their body weight compared to normal rats. Body weight was increased in diabetic rats treated with $P$. farcta compared to those with untreated diabetic rats. Diabetic rats treated with extract of leaves of $P$. farcta showed the highest improvement in the body weight compared with other extracts of the plant. It did not reach the level of insulin effect. The results showed an important role of the $P$. farcta extracts in the weights of diabetic rats.

Effect of $\boldsymbol{P}$. farcta extracts (roots, leaves and fruits) on hematological parameters in alloxan induced diabetic rats

Table 3 reveals the effect of $P$. farcta extracts on RBC and related indices $(\mathrm{Hb}, \mathrm{HCT}, \mathrm{MCV}, \mathrm{MCH} \& \mathrm{MCHC})$ in diabetic male rats. Diabetes induction caused a decrease in the $\mathrm{RBC}$ count and related indices ( $\mathrm{Hb}, \mathrm{HCT}, \mathrm{MCV}, \mathrm{MCH}$ $\& \mathrm{MCHC}$ ) compared to normal control rats. Administration of root and fruit extract showed significant improvement an $\mathrm{RBC}$ count in diabetic rats in insulin like manner.
Administration of root extract increased $\mathrm{Hb} \& \mathrm{HCT}$ in diabetic rats. $\mathrm{MCV}$ and $\mathrm{MCHC}$ were not improved by all extracts in diabetic rats.

Table 2: Effect of $P$. farcta extracts (roots, leaves and fruits) on the body weight in normal and alloxan induced diabetic rats

\begin{tabular}{lcc}
\hline \multirow{2}{*}{ Animal groups } & \multicolumn{2}{c}{ Body weight $(\mathrm{g})$} \\
\cline { 2 - 3 } & before T & after T \\
\hline Normal Control & $237.4 \pm 3.572$ & $286.2 \pm 8.857 * \mathrm{a}$ \\
Diabetic rats & $221.0 \pm 4.301$ & $194.0 \pm 5.339 * \mathrm{~b}$ \\
D+ root extract & $225.0 \pm 5.000$ & $249.0 \pm 13.93 * \mathrm{c}$ \\
D+ leaves extract & $228.0 \pm 3.742$ & $265.0 \pm 13.36 * \mathrm{~d}$ \\
D+ fruits extract & $221.0 \pm 4.301$ & $245.0 \pm 2.236 * \mathrm{c}$ \\
D+ insulin & $226.0 \pm 4.301$ & $295.0 \pm 5.701 * \mathrm{e}$ \\
\hline
\end{tabular}

Results expressed as mean \pm St. error. ${ }^{*}$ means significant difference at $\mathrm{P}<0.05$ in the same rows. The same letters in the same column mean non-significant difference among extracts as well as insulin, while the different letters mean significant difference among extracts as well as insulin at $\mathrm{P}<0.05, \mathrm{D}=$ Diabetic rats, $\mathrm{T}=$ treatment. 
Table 3: Effect of P. farcta extracts (roots, leaves and fruits) on RBC and related indices in alloxan induced diabetic rats

\begin{tabular}{lcccccc}
\hline Parameters & Control & Diabetic & D+root extract & D+leaves extract & D+fruits extract & D+ insulin \\
\hline RBC $* 10^{6} / \mu \mathrm{l}$ & $6.966 \pm 0.155^{\mathrm{c}}$ & $5.266 \pm 0.330^{\mathrm{a}}$ & $6.350 \pm 0.206^{\mathrm{c}}$ & $5.406 \pm 0.249 \mathrm{ab}$ & $6.486 \pm 0.153^{\mathrm{c}}$ & $6.126 \pm 0.144^{\mathrm{abc}}$ \\
$\mathrm{Hb}(\mathrm{g} / \mathrm{dl})$ & $11.25 \pm 0.357^{\mathrm{d}}$ & $9.108 \pm 0.313^{\mathrm{a}}$ & $10.95 \pm 0.286^{\mathrm{cd}}$ & $9.798 \pm 0.189^{\mathrm{abc}}$ & $9.522 \pm 0.370^{\mathrm{ab}}$ & $10.62 \pm 0.244^{\mathrm{bcd}}$ \\
$\mathrm{HCT}$ & $36.60 \pm 0.768^{\mathrm{b}}$ & $30.00 \pm 1.682^{\mathrm{a}}$ & $34.76 \pm 0.821^{\mathrm{b}}$ & $34.29 \pm 0.328^{\mathrm{ab}}$ & $33.31 \pm 1.110^{\mathrm{ab}}$ & $34.27 \pm 1.102^{\mathrm{ab}}$ \\
MCV (fl) & $57.03 \pm 0.516^{\mathrm{b}}$ & $54.24 \pm 0.601^{\mathrm{a}}$ & $54.91 \pm 0.453^{\mathrm{a}}$ & $54.37 \pm 0.270^{\mathrm{a}}$ & $54.71 \pm 0.471^{\mathrm{a}}$ & $54.35 \pm 0.459^{\mathrm{a}}$ \\
MCH (pg) & $17.42 \pm 0.156^{\mathrm{b}}$ & $15.06 \pm 0.082^{\mathrm{a}}$ & $16.60 \pm 0.218^{\mathrm{b}}$ & $15.26 \pm 0.334^{\mathrm{a}}$ & $15.23 \pm 0.235^{\mathrm{a}}$ & $15.07 \pm 0.156^{\mathrm{a}}$ \\
MCHC & $30.70 \pm 0.733^{\mathrm{b}}$ & $27.72 \pm 0.634^{\mathrm{a}}$ & $29.03 \pm 0.552^{\mathrm{ab}}$ & $28.61 \pm 0.653^{\mathrm{ab}}$ & $28.00 \pm 0.544^{\mathrm{a}}$ & $30.10 \pm 0.351^{\mathrm{ab}}$ \\
\hline
\end{tabular}

Results expressed as mean \pm St. error. The same letters in the same row mean non-significant difference, while the different letters mean significant difference at $\mathrm{P}<0.05, \mathrm{D}=$ diabetic.

Table 4, shows the effect of $P$. farcta extracts on total and differential WBC count in alloxan induced diabetic rats. WBCs increased in diabetic rats. Treatments with all extracts of $P$. farcta improved the total number of the
WBCs. Leave and fruit extracts showed increasing in neutrophil in diabetic rats, while root extract didn't show any changes in neutrophil values in these rats. Lymphocytes and Monocytes were not change in diabetic rats.

Table 4: Effect of $P$. farcta extracts (roots, leaves and fruits) on total \& differential WBC count in alloxan induced diabetic rats

\begin{tabular}{lcccccc}
\hline Parameters & Control & Diabetic & D+root extract & D+leaves extract & D+fruits extract & D+ insulin \\
\hline WBC $^{*} 10^{3} / \mu \mathrm{l}$ & $7.392 \pm 0.167^{\mathrm{a}}$ & $9.536 \pm 0.312^{\mathrm{b}}$ & $8.000 \pm 0.231^{\mathrm{a}}$ & $8.040 \pm 0.168^{\mathrm{a}}$ & $8.360 \pm 0.297^{\mathrm{a}}$ & $7.864 \pm 0.274^{\mathrm{a}}$ \\
Neutrophil & $23.66 \pm 0.916^{\mathrm{a}}$ & $19.42 \pm 0.866^{\mathrm{a}}$ & $22.86 \pm 1.065^{\mathrm{a}}$ & $39.56 \pm 1.094^{\mathrm{b}}$ & $37.44 \pm 2.521^{\mathrm{b}}$ & $21.52 \pm 1.104^{\mathrm{a}}$ \\
Lymphocyte & $62.08 \pm 2.086^{\mathrm{bc}}$ & $66.16 \pm 1.582^{\mathrm{c}}$ & $64.24 \pm 1.087^{\mathrm{bc}}$ & $51.02 \pm 1.026^{\mathrm{a}}$ & $56.04 \pm 1.401^{\mathrm{ab}}$ & $57.12 \pm 3.248^{\mathrm{ab}}$ \\
Monocyte & $16.46 \pm 1.286^{\mathrm{bc}}$ & $15.96 \pm 0.747^{\mathrm{bc}}$ & $14.68 \pm 0.485^{\mathrm{b}}$ & $9.220 \pm 0.401^{\mathrm{a}}$ & $8.600 \pm 0.738^{\mathrm{a}}$ & $19.50 \pm 1.585^{\mathrm{c}}$ \\
\hline
\end{tabular}

Results expressed as mean \pm St. error. The same letters in the same row mean non-significant difference, while the different letters mean significant difference at $\mathrm{P}<0.05, \mathrm{D}=$ diabetic.

Effect of $P$. farcta extracts (roots, leaves and fruits) $(200$ $\mathrm{mg} / \mathrm{kg}$ ) on lipid profile levels in alloxan induced diabetic rats

Table 5, shows that lipid profile levels (TC, TG, VLDL and LDL) were significantly increased in diabetic rats, whereas, high-density lipoprotein HDL was decreased.
Root, leaves, fruit extracts administration caused a decrease in the level of TC, TG and VLDL in the diabetic rats compared to non-treated diabetic rats, while treatments with all extracts did not caused changes in HDL and LDL levels in diabetic rats.

Table 5: Effect of P. farcta extracts (roots, leaves and fruits) on lipid profile levels in alloxan induced diabetic rats

\begin{tabular}{lcccccc}
\hline Parameters & Control & Diabetic & D+root extract & D+leaves extract & D+fruits extract & D+ insulin \\
\hline TC & $65.01 \pm 1.453^{\mathrm{a}}$ & $117.8 \pm 7.303^{\mathrm{c}}$ & $71.78 \pm 2.113^{\mathrm{ab}}$ & $70.65 \pm 1.493^{\mathrm{ab}}$ & $83.87 \pm 2.808^{\mathrm{b}}$ & $68.00 \pm 1.986^{\mathrm{a}}$ \\
TG & $38.49 \pm 1.608^{\mathrm{a}}$ & $85.12 \pm 1.933^{\mathrm{d}}$ & $70.05 \pm 1.600^{\mathrm{c}}$ & $71.23 \pm 1.839^{\mathrm{c}}$ & $75.08 \pm 2.005^{\mathrm{c}}$ & $52.03 \pm 3.024^{\mathrm{b}}$ \\
HDL & $45.15 \pm 2.278^{\mathrm{c}}$ & $31.09 \pm 0.469^{\mathrm{a}}$ & $35.69 \pm 1.068^{\mathrm{ab}}$ & $34.69 \pm 1.527^{\mathrm{ab}}$ & $35.96 \pm 1.077^{\mathrm{ab}}$ & $38.04 \pm 1.637^{\mathrm{b}}$ \\
VLDL & $7.700 \pm 0.322^{\mathrm{a}}$ & $17.02 \pm 0.386^{\mathrm{d}}$ & $14.01 \pm 0.320^{\mathrm{c}}$ & $14.25 \pm 0.369^{\mathrm{c}}$ & $15.02 \pm 0.400^{\mathrm{c}}$ & $10.41 \pm 0.605^{\mathrm{b}}$ \\
LDL & $21.16 \pm 1.424^{\mathrm{a}}$ & $54.72 \pm 2.100^{\mathrm{e}}$ & $42.78 \pm 1.159^{\mathrm{bc}}$ & $47.90 \pm 1.571^{\mathrm{cd}}$ & $49.52 \pm 0.823^{\mathrm{de}}$ & $39.55 \pm 1.503^{\mathrm{b}}$ \\
\hline
\end{tabular}

Results expressed as mean \pm St. error. The same letters in the same row mean non-significant difference, while the different letters mean significant difference at $\mathrm{P}<0.05, \mathrm{D}=$ diabetic.

\section{Discussion}

This study showed improvement of body weight gain by $P$. farcta extracts, perhaps by controlling the level of glucose as well as controlling muscle wasting and induced adipogenesis (13). Since diabetes is characterized by a rising of glycosylation of $\mathrm{RBC}$ membrane proteins, therefore anemia is usually occurred by the destruction of these cells (14). Over time, these proteins may be oxidized and lipid peroxidation will occur that leads to hemolysis of RBC (15). Reducing RBC, Hb, MCHC, MCH, HCT (PCV) and MCV levels in the diabetic rats in this study may be due to the abnormalities (that caused by diabetes) on the normal body systems. This result is concordant a previous study reported a reduction of RBC indices in streptozotocin-induced diabetic rats (16). The decrease in 
these measures is the cause of anemia (17). Usually, diabetic case affects kidneys causing impairment in the production of erythropoietin hormone, which is responsible for blood constituents' production including $\mathrm{RBC}$, leading to reduction red blood cells production (18). Administration of the extracts of $P$. farcta (in our study) to the diabetic rats caused improvement in RBC, Hb, HCT and MCH levels. This improvement may be attributed in the components of plant extract that can stimulate the formation or secretion of erythropoietin in the stem cells of the animals which stimulates red blood cells production in bone marrow (19), stimulation helps the formation of $\mathrm{RBC}$, improvement of $\mathrm{MCH}$ and $\mathrm{MCHC}$ (20).

White blood cells (WBCs) increased in alloxan induced diabetic rats in this study that resulted in complications of diabetes, these complications may increase the number of WBCs (21). WBCs can be activated by advanced glycation end products, oxidative stress, angiotensin II, and cytokines in a state of hyperglycemia (22). Administration of plant extracts in this study restores the WBC count near normal count. This effect could be attributed to some phytochemicals in these extracts that regulate the production of white blood count in the treated rats (23).

Dyslipidemia manifested by elevation in serum TC, TG, VLDL-C and LDL-C have been increased in the diabetic rats, these patterns of lipid profile changes are very common in diabetes (5). In this study, the treatments with plant extracts and insulin decreased the levels of TC, TG, VLDL and LDL in diabetic rats with increased HDL levels. Insulin can suppress adipose tissue lipolysis that prevents or diminish delivery of free fatty acids to the liver. This leads to inhibit the synthesis of excess TG in the liver, which is driven by this providing of fatty acids and the accumulation of excess liver fat. Then this leads to cut the sequence of the processes that lead to dyslipidemia (24). The result of the current study is similar to the results obtained by (25). The improvement in diabetes due to the extract may increase the use of glucose by the body, which may reduce fat mobilization. Also, the plant extract may have stimulated lipoprotein lipase activities resulting in a decrease of plasma TG and probably, increase the uptake of triglyceride from plasma by skeletal muscle and adipose tissues (26). Phytochemical compounds like phenols, tannins, alkaloids, steroids, cardiac glycosides, flavonoids and terpenes present in this extract have been reported possess antilipidemic activity (27).

\section{Conclusion}

It is concluded that $P$. farcta extracts especially root extract could improve body weight, serum glucose, hematology parameters in diabetic case, which may enhance it to use as a medicine against diabetes.

\section{Acknowledgments}

Thanks to God. I thank Department of Biology, College of Science, University of Salahuddin, Erbil, Iraq.

\section{References}

1. Dashtban M,Sarir H,Omidi A.The effect of Prosopis farcta beans extract on blood biochemical parameters in streptozotocin- induced diabetic male rats. Adv Biomed Res. 2016; 5:116. DOI:10.4103/22779175.185575

2. Afifi, F. Hypoglycemic effect of Prosopis fracta. Int J Pharmacog, 1993;31:161-164. https://doi.org/10.3109/13880209309082933.

3. Gasim GI. Glycated hemoglobin and red blood cell indices in non-diabetic pregnant women. Clin Pract. 2017; 7:999. DOI:10.4081/cp.2017.99.

4. Vatcheva KP, Fisher SP, Mohammad H, Rahbar MH, Lee MJ, Olvera RL, Mccormick JB. Association of total and differential with blood cell counts to development of type 2 diabetes in Mexican Americans in cameron country hispanic cohort. Diab Res. 2015;1(4):103-112. DOI: $10.17140 / \mathrm{DROJ}-1-117$.

5. Schofield JD, Liu Y, Rao-Balakrishna P, Malik RA, Soran, H. Diabetes dyslipidemia. Diab Ther. 2016;7(2):203-219.

6. Beejmohun V, Peytavy M, Mignon C, Muscente D, Deplanque X, Ripoll C, Chapal N. Acute effect of Ceylon cinnamon extract on postprandial glycemia: Alpha-amylase inhibition, starch tolerance test in rats, and randomized crossover clinical trial in healthy volunteers. BMC Comp Alter Med. 2014;14:351. DOI: 10.1186/14726882-14-351.

7. Omidi A, Ansari H, Ghazaghi M. Prosopis farcta beans increase HDL cholesterol and decrease LDL cholesterol in ostriches (Struthio camelus). Trop Anim Health Prod. 2013;45(2):431-434. DOI: 10.1007/s11250-012-0234-x.

8. Szkudelski T. The mechanism of alloxan and streptozotocin action in $\beta$ - Cells of the rat pancreas. Physiol Res. 2001;50:536-546.

9. Ukwenya VO, Ashaolu OJ, Adeyemi DO, Abraham KJ. Experimental diabetes and the epididymis of wistar rats: The protective effects of Anacardium occidentale (Linn.). J Exp Clin Anat. 2015;14:57-62.DOI: 10.4103/1596-2393.177029.

10. Purves RD. Optimum numerical integration methods for estimation of area-under-the -curve (AUC) and area-under-the-momentcurve (AUMC). J Phamacokinet Biopharm.1992;20:211-26.DOI: $10.1007 / \mathrm{bf01062525.}$

11. Hassan S, Abd El-Twab S, Hetta M, Mahmoud B. Improvement of lipid profile and antioxidant of hypercholesterolemic albino rats by polysaccharides extracted from the green alga Ulva lactuca Linnaeus. Saudi J Biol Sci. 2011;18(4):333-340. DOI: 10.1016/j.sjbs.2011.01.005.

12. Ikeme JC, Pergola PE, Scherzer R, Shlipak MG, Benavente OR,Peralta CA. Post Hoc Analyses of Randomized Clinical Trial for the Effect of Clopidogrel Added to Aspirin on Kidney Function. Clinical Journal of the American Society of Nephrology. 2017; 12 (7) 1040-1047. DOI: $10.2215 /$ CJN.00100117.

13. Shenoy AG, Ramesh KG. Improvement of insulin sensitivity by perindopril in spontaneously hypertensive and streptozotocin induced diabetic rats. Indian J Pharmacol. 2002;34:156-164.

14. Oyedemi SO, Yakubu MT, Afolayan AJ. Antidiabetic activities of aqueous leaves extract of Leonotis leonurus in streptozotocin induced diabetic rats. J Med Plant Res. 2011;5(1):119-125.

15. Arun GS, Ramesh KG. Improvement of insulin sensitivity by perindopril in spontaneously hypertensive and streptozotocin-diabetic rats. Indian J Pharmacol. 2002;34:156-164.

16. Baskar R, Bhakshu LM, Bharathi GV, Reddy SS, Karuna R, Reddy GK. Antihyperglycemic activity of aqueous root extract of Rubia 
cordifolia in streptozotocin-induced diabetic rats. Pharm Biol. 2006;44(6):475-479. DOI: 10.1080/13880200600798593.

17. Balasubraimanian T, Lal MS, Mahananda S, Chatterjee TK. Antihyperglycemic and antioxidant activities of medicinal plant Stereospermum suaveolens in streptozotocin-induced diabetic rats. J Diet Suppl. 2009;6(3):227-251. DOI: 10.1080/13880200600798593.

18. Bosman DR, Winkler AS, Marsden JT, Macdougall IC, Watkins PJ. Anemia with erythropoietin deficiency occurs early in diabetic nephropathy. Diab Care. 2001;24(3):495-499. DOI:10.2337/diacare.24.3.495.

19. Ohlsson A. Early erythropoietin for preventing red blood cell transfusion in preterm and/or low birth weight infants. Cochrane Database Syst Rev. 2006;3: CD004863.DOI: 10.1002/14651858.CD004863.

20. Abu-Zaiton AS. Antidiabetic activity of Ferula asafoetida extract in normal and alloxan induced diabetic rats. Pak J Biol Sci. 2010;13(2):97-100. DOI: 10.3923/pjbs.2010.97.100.

21. Woo SJ, Ahn SJ, Ahn J, Park KH, Lee K. Elevated systemic neutrophil count in diabetic retinopathy and diabetes: A hospitalbased cross-sectional study of 30,793 Korean subjects. Ophthalmol Vis Sci. 2011;52:7697-703.DOI: 10.1167/iovs.11-7784.
22. Mahmoud AM. Hematological alterations in diabetic rats role of adipocytokines and effect of citrus flavonoids. Exp Clin Sci J. 2013;12:647-657. DOI: 10.17877/DE290R-7264.

23. Akinpelu DA, Aiyegoro OA, Okoh AI. In vitro antimicrobial and phytochemical properties of crude extract of stem bark of Afzelia africana (Smith). Afr J Biotechnol. 2008;7(20):3665 -3670. DOI: 10.4314/ajb.v7i20.59407.

24. Bugianesi E, Gastaldelli A, Vanni E, Gambino R, Cassader M, Baldi $\mathrm{S}$, Ponti V, Pagano G, Rizzetto M. Insulin resistance in non-diabetic patients with non-alcoholic fatty liver disease: Sites and mechanisms. Diab Etiol. 2005;48(4):634-642. DOI: 10.1007/s00125-005-1682- x.

25. Amaechi D, Udosen EO, Edet EE, Asanga EE, Mbakwe IE. Lipid profile status of streptozotocin induced diabetic rats treated with ethanolic leaf extract of Solenostemon monostachyus. J Med Plts Res. 2015;9(8):289-293. DOI: 10.5897/JMPR2014.5663.

26. El-Hazmi MA, Warsy AS. Evaluation of serum cholesterol and triglyceride levels in 1-6-year-old Saudi children. J Trop Pediat. 2001;47:181-185. DOI: 10.1093/tropej/47.3.181.

27. Tandon S. Phytochemicals and cardiovascular health. Curr R D High. 2005;28:18-22. 